\title{
THE INFLUENCE OF ERYTHROCYTE FACTORS ON THEIR SEDIMENTATION RATE
}

\author{
BY \\ DAVID PHEAR \\ From the Bland Sutton Institute, Middlesex Hospital, London
}

(RECEIVED FOR PUBLICATION JANUARY 21, 1957)

The erythrocyte sedimentation rate (E.S.R.) of a blood sample is chiefly determined by the concentration of many plasma factors, which interact with extreme complexity to hasten or retard roukeau formation (Hewson, 1777 ; Cutler, Park, and Herr, 1938 ; Wintrobe, 1951). A less important but definite part is played by variations in the properties of the erythrocytes.

Abnormalities of red cell shape have been shown by several workers to inhibit rouleau formation, and so to retard sedimentation. Wiltshire (1912-13) observed such low rates due to anisocytosis and poikilocytosis; Bönniger and Herrmann (1923), working with the red cells of chlorosis, Lattes (1925) with spherocytes, and Bunting (1939) with sickle cells, all described similar slow sedimentation. The abnormal and irregular shapes of such red cells probably decrease the area of their flat surfaces in contact with one another, and so inhibit their arrangement in rouleaux.

Early quantitative work on the effect of red cell size was done by Marloff (1919), Bürker (1922), and Ohno (1926) ; these workers studied the sedimentation of erythrocytes of man and domestic animals, suspended at a dilution of 1 in 200 in Hayem's solution. Under these conditions the red cells fall individually without forming rouleaux. The E.S.R. was found to increase in parallel with increase of cell radius and of mean corpuscular haemoglobin concentration (M.C.H.C.).

Newham and Martin (1928), on the other hand, found that the E.S.R. and amount of rouleau formation of a series of bloods was quite unrelated to the cell size; in addition they concluded on theoretical and experimental grounds that the cell specific gravity was unimportant in varying the E.S.R. Bendien, Neuberg, and Snapper (1932) estimated the specific gravity of normal red cells to be 1.08 to 1.09 , with a range in pathological states of 1.06 to 1.11 , while that of the plasma remained constant at 1.03 . They suggested, there- fore, that variations in the specific gravity of the cell might be important. They also developed a formula for calculating the E.S.R., based on the concentrations of fibrinogen and globulin in the blood, and on the packed cell volume (P.C.V.). When cells of a high colour index from pernicious anaemia, and a low colour index from secondary anaemia, were suspended in the same plasma at the same P.C.V., the high colour index cells gave an unexpectedly high E.S.R. reading and the low ones an unexpectedly low result ; their calculated E.S.R. had to be multiplied by the colour index to give an approximation to the observed E.S.R.

Ham and Curtis (1938), in a small series of experiments, resuspended cells of varying size in the plasma of other patients ; they found that the larger the cells the faster the E.S.R., but that there was no relation between E.S.R. and M.C.H.C.

Cutler et al. (1938) state that differences in specific gravity of cell and plasma are unimportant, and that the individual size, shape, and haemoglobin content of the red cell can be disregarded, as it is the size of the whole aggregated rouleau that determines the E.S.R.

Thygesen (1942) also considers that variations in specific gravity are unimportant; the E.S.R. is controlled almost exclusively by the rouleauforming properties of the plasma.

Poole and Summers (1952) compared the sedimentation rates of cells from various anaemias with those of normal cells, in both the normal and the anaemic plasmas ; they found the cells of irondeficiency and post-haemorrhagic anaemias, and of the symptomatic anaemia of carcinoma, sedimented more slowly than normal cells in both the anaemic and the normal plasmas. Macrocytic cells in normal plasma sedimented slightly faster than normal cells, but in their own plasma considerably faster than normal cells. Poole and Summers suggest that the decreased sedimentation of the first group of anaemias might be related to anisocytosis. 


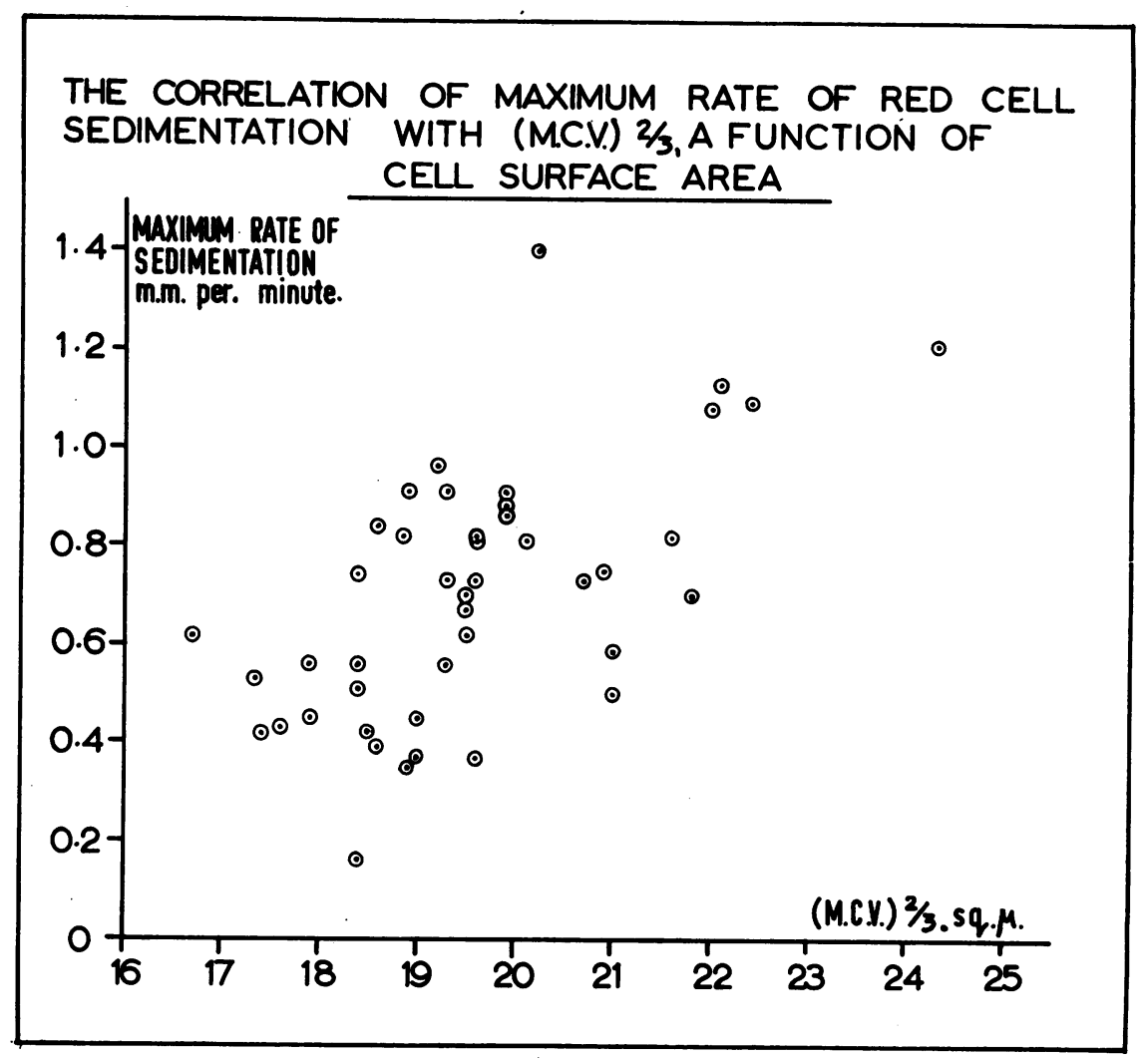

FIG. 1

There is, then, disagreement about the part played by red cell factors in determining sedimentation rates, and to elucidate this question the present experiments were designed. The sedimentation rates of red cell samples of varying size from 44 different patients were observed, all suspended in the plasma of one donor in order to eliminate the effects of plasma factors

\section{Method}

The blood samples were collected with Wintrobe's oxalate anticoagulant mixture, washed three times in saline and then in donor's plasma, and re-suspended in donor's plasma to give a P.C.V. of approximately $25 \%$; cells of $\mathrm{ABO}$ groups incompatible with the donor serum were excluded. These experimental suspensions were then set up in Wintrobe sedimentation tubes, and the rate of fall observed at frequent intervals, and the maximum rate of fall estimated in each case. These maximum rates were corrected to the mean P.C.V. of the experimental series by the method of Rourke and Ernstene (1930); the mean P.C.V. was $25.5 \%, \sigma=5.2$, so that only comparatively minor corrections were required. On each occasion a control sedimentation test was performed on the donor's blood. There were small variations in the control value, related to variations of the experimental temperature between $20^{\circ} \mathrm{C}$. and $24^{\circ} \mathrm{C}$. The mean control E.S.R. was therefore estimated $(13.1 \mathrm{~mm}$. $/ \mathrm{hr}$, $\sigma=0.57$ ), and the result of each experiment was corrected for variations in the control by multiplication by the factor

Control E.S.R. on the day of experiment

$$
13.1
$$

Red cells were counted by standard methods, two separate pipette dilutions of each blood sample being counted (Wintrobe, 1951).

\section{Results and Calculation}

The maximum sedimentation rate of each sample was plotted against (M.CV.) $)^{2 / 3}$, a figure that is proportional to the square of the mean radius of the cells of the sample and therefore to their surface area ; a high degree of positive correlation was found (Fig. 1, where $\mathrm{r}=0.61, \mathrm{P}<0.001$ ). On the other hand, when the maximum sedimentation rate was plotted against the M.C.H.C., a figure on which mainly depends the specific gravity of the cell sample, an insignificant degree of correlation was found $(r=0.31,0.05>P>0.02)$. 
The rate of sedimentation of red cells varies, therefore, with their surface area rather than with their specific gravity.

\section{Conclusion}

The literature relating to the effect of red cell factors on their sedimentation rate is reviewed. In experiments with 44 blood samples, the sedimentation rate was found to increase with increasing cell size; there was no correlation between mean corpuscular haemoglobin concentration and the sedimentation rate.

I wish to thank Dr. J. W. Stewart and Dr. F. G. J. Hayhoe for help with this work.

\section{REFERENCES}

Bendien, W. M., Neuberg, J., and Snapper, I. (1932). Biochem. Z., 247, 306.

Bönniger, M., and Herrmann, W. (1923). Klin. Wschr., 2, 744.

Bunting, H. (1939). Amer. J. med. Sci., 198, 191.

Bürker, K. (1922). Münch. med. Wschr., 69, 577

Cutler, J. W., Park, F. R., and Herr, B. S. (1938). Amer. J. med. $S c i, 195,734$.

Ham, T. H., and Curtis, F. C. (1938). Medicine (Baltimore,) 17, 447.

Hewson, W. (1777). Experimental Enquiries, Pt. III, p. 28. Longmans, London.

Lattes, L. (1925). Die Individualität des Blütes in der Biologie in der Klinik und in der gerichtlichen Medizin. Springer, Berlin.

Marloff, R. (1919). Pfûgers Arch. ges. Physiol., 175, 355.

Newham, H. B., and Martin, P. H. (1928). Quart. J. Med., 22, 145.

Ohno, M. (1926). Z. ges. exp. Med., 52, 643.

Poole, J. C. F., and Summers, G. A. C. (1952). Brit. med. J., 1, 353.

Rourke, M. D., and Ernstene, A. C. (1930). J. clin. Invest., 8, 545.

Thygesen, J. E. (1942). Acta med. scand., Suppl. 134.

Wiltshire, H. (1912-13). J. Path. Bact., 17, 282.

Wintrobe, M. M. (1951). Clinical Hematology, 3rd ed. Lea and Febiger, Philadelphia. 